University of Nebraska - Lincoln

DigitalCommons@University of Nebraska - Lincoln

Detection of enterohemorrhagic Escherichia coli 0157:H7 by using a multiplex real-time PCR assay for genes encoding intimin and Shiga toxins

\author{
Vijay K. Sharma \\ USDA-ARS, vsharma@nadc.ars.usda.gov \\ Evelyn A. Dean-Nystrom \\ Pre-Harvest Food Safety and Enteric Diseases Research Unit, evelyn.nystrom@ars.usda.gov
}

Follow this and additional works at: https://digitalcommons.unl.edu/usdaarsfacpub

Part of the Agricultural Science Commons

Sharma, Vijay K. and Dean-Nystrom, Evelyn A., "Detection of enterohemorrhagic Escherichia coli 0157:H7 by using a multiplex real-time PCR assay for genes encoding intimin and Shiga toxins" (2003).

Publications from USDA-ARS / UNL Faculty. 941.

https://digitalcommons.unl.edu/usdaarsfacpub/941

This Article is brought to you for free and open access by the U.S. Department of Agriculture: Agricultural Research Service, Lincoln, Nebraska at DigitalCommons@University of Nebraska - Lincoln. It has been accepted for inclusion in Publications from USDA-ARS / UNL Faculty by an authorized administrator of DigitalCommons@University of Nebraska - Lincoln. 


\title{
Detection of enterohemorrhagic Escherichia coli O157:H7 by using a multiplex real-time PCR assay for genes encoding intimin and Shiga toxins
}

\author{
Vijay K. Sharma*, Evelyn A. Dean-Nystrom \\ Pre-Harvest Food Safety and Enteric Diseases Research Unit, National Animal Disease Center, \\ USDA, Agricultural Research Service, Ames, IA 50010, USA
}

Received 9 August 2002; received in revised form 31 December 2002; accepted 20 January 2003

\begin{abstract}
A multiplex real-time PCR (R-PCR) assay was designed and evaluated on the ABI 7700 sequence detection system (TaqMan) to detect enterohemorrhagic Escherichia coli (EHEC) O157:H7 in pure cultures, feces, and tissues. Three sets of primers and fluorogenic probes were used for amplification and real-time detection of a 106-bp region of the eae gene encoding EHEC O157:H7-specific intimin, and 150-bp and 200-bp segments of genes stx 1 and stx2 encoding Shiga toxins 1 and 2, respectively. Analysis of 67 bacterial strains demonstrated that the R-PCR assay successfully distinguished EHEC O157:H7 serotype from non-O157 serotypes and provided accurate profiling of genes encoding intimin and Shiga toxins. Bacterial strains lacking these genes were not detected with this assay. The detection range of the R-PCR assay for the three genes was linear over DNA concentrations corresponding from $10^{3}$ to $10^{8} \mathrm{CFU} / \mathrm{ml}$ of EHEC O157:H7. The R-PCR allowed construction of standard curves that facilitated quantification of EHEC O157:H7 in feces and intestinal tissues. Detection sensitivity of the R-PCR assay ranged from $10^{4}$ to $10^{8} \mathrm{CFU} / \mathrm{g}$ of feces or tissues without enrichment. Enrichment of feces in a non-selective broth for 4 and $16 \mathrm{~h}$ resulted in the detection of levels (from $10^{0}$ to $10^{3} \mathrm{CFU} / \mathrm{g}$ of feces) considered sufficient for infection in humans. The R-PCR assay for $e a e_{\mathrm{O} 157: \mathrm{H} 7}$, stxl, and stx2 proved to be a rapid test for detection of EHEC O157:H7 in complex biological matrices and could also potentially be used for quantification of EHEC O157:H7 in foods or fecal samples.

Published by Elsevier Science B.V.
\end{abstract}

Keywords: Escherichia coli; Shiga toxins; Hemorrhagic colitis

\footnotetext{
* Corresponding author. Tel.: +1-515-663-7406/7279; fax: +1-515-663-7458.

E-mail address: vsharma@nadc.ars.usda.gov (V.K. Sharma).
} 


\section{Introduction}

Enterohemorrhagic Escherichia coli (EHEC) and other Shiga toxin-producing E. coli (STEC) are important food-borne pathogens associated with severe gastrointestinal and systemic diseases, such as hemorrhagic colitis (HC) and hemorrhagic-uremic syndrome (HUS), in humans (Karmali, 1989). Although more than 200 serotypes of STEC have been identified, EHEC O157:H7 is implicated in the vast majority of outbreaks and sporadic cases of bloody diarrhea in North America (Wells et al., 1983). Most human EHEC O157:H7 infections are caused by consumption of contaminated food and water, and cattle are generally considered the major reservoir for EHEC O157:H7 and other STEC serotypes that have been isolated from human clinical cases (Griffin and Tauxe, 1991; Hancock et al., 1994).

PCR has become a useful technique for detection of pathogens because it is quick, specific, sensitive and relatively inexpensive. A number of PCR-based assays have recently been developed for detection of EHEC O157:H7 in foods and feces. Some of these assays have targeted only stx genes (Ramotar et al., 1995; Witham et al., 1996) while others have included stx and one or more EHEC O157:H7-specific genetic markers (Fratamico et al., 1995; Gannon et al., 1997a; Paton and Paton, 1998). PCR-based assays that used primers to amplify and detect stxl and stx2 could not distinguish EHEC O157:H7 from non-O157 STEC. Although PCR assays targeting highly divergent $3^{\prime}$ one-third of the gene eae had facilitated detection of EHEC O157:H7 from other eae-harboring STEC, enteropathogenic E. coli (EPEC), Citrobacter rodentium and Hafnia alvei, these assays could not identify Shiga toxins associated with EHEC O157:H7. Moreover, quantitative detection of amplification products was not feasible in any of these PCR assays because agarose gel electrophoresis and ethidium bromide staining were used for visualizing PCR amplified products.

Recently, real-time PCR (R-PCR) assays have been developed for detection and quantification of pathogen-specific gene products by using TaqMan probes or molecular beacons (Lyons et al., 2000; Nogva et al., 2000). TaqMan probes and molecular beacons are oligonucleotides that are conjugated to reporter and quencher dyes at $5^{\prime}$ and $3^{\prime}$ ends, respectively. In an intact probe or a beacon, the quencher dye suppresses the fluorescence emission of the reporter dye. However, the modification of a TaqMan probe (hydrolysis by Taq polymerase to cleave reporter moiety from the probe) or a conformational change in a molecular beacon during annealing and extension phases of the PCR process results in an increase in the reporter dye's fluorescence intensity. The continuous measurement of incremental fluorescence increase at each PCR cycle provides an accurate estimate of the number of cells of a bacterial pathogen present in a contaminated food or fecal sample. Incorporation of fluorogenic probes in PCR assays provides an additional element of specificity that eliminates the need for downstream analysis of amplified products by agarose gel electrophoresis and use of additional tests for confirming identity of amplified products. A few R-PCR assays have been developed for the detection of EHEC O157:H7 (Bellin et al., 2001; Fortin et al., 2001; Oberst et al., 1998). In these assays, however, detection of EHEC 0157:H7 was based on an amplification and detection of a single gene.

The objective of the present study was to develop a R-PCR assay for simultaneous amplification and detection of eae, stx 1 , and stx 2 , the three important virulence genes of 
EHEC O157:H7 in a single PCR assay, and evaluate the utility of this PCR to detect EHEC O157:H7 in feces and tissues obtained from weaned calves and neonatal pigs inoculated with a streptomycin-resistant EHEC O157:H7. The detection sensitivity of this PCR assay was compared with the detection of a streptomycin-resistant EHEC O157:H7 by direct plating of feces and tissues on SMAC agar containing streptomycin. We also examined the effect of enrichment on detection sensitivity of the R-PCR assay by culturing feces for 4 to $16 \mathrm{~h}$ in a non-selective broth.

\section{Materials and methods}

\subsection{Bacterial strains, culture media, and growth conditions}

A total of 67 bacterial strains containing various combinations of stx and eae genes were used for evaluating the specificity of the real-time PCR assay for EHEC O157:H7 detection. These strains have previously been characterized genotypically (Sharma et al., 1999). Bacterial strains were propagated and maintained on trypticase soy agar (TSA) plates. Liquid cultures were obtained by growing bacteria in GNTSB [prepared by mixing equal volumes of gram-negative broth (GNB) and trypticase soy broth (TSB)] for $16 \mathrm{~h}$ at $37{ }^{\circ} \mathrm{C}$ with continuous agitation $(160 \mathrm{rpm})$ in a circulating air incubator (New Brunswick Scientific, Edison, NJ, USA). TSA and sorbitol-MacConkey (SMAC; with or without streptomycin at $50 \mu \mathrm{g} / \mathrm{ml}$ ) agar were used to enumerate bacteria. TSA, GNB, and TSB were purchased from BBL (Becton Dickinson Microbiology Systems, Cockeysville, MD, USA) and sorbitol-MacConkey agar (SMAC) was from DIFCO Laboratories (Becton Dickinson Laboratories, Sparks, MD, USA).

\subsection{Design of primers and fluorogenic probes}

The nucleotide sequences of primers and fluorogenic probes and expected sizes of amplified products are listed in Table 1 . About 800 nucleotides at the $3^{\prime}$ end of a previously published sequence of an eae gene, encoding EHEC O157:H7-specific intimin (Beebakhee et al., 1992), were taken into consideration for selecting primers and a probe to amplify and detect 106-bp fragment specific for the eae gene of EHEC O157:H7 (eae $\left.e_{\mathrm{O} 157: \mathrm{H} 7}\right)$. A comparison of the nucleotide sequences of $e a e_{\mathrm{O} 157: \mathrm{H} 7^{-}}$-specific primers and probe set with the sequences deposited in the GenBank revealed that this primer and probe set could distinguish EHEC O157:H7 from non-O157 EHEC and EPEC serotypes (with the exception of EPEC O55:H7 which carry an eae allele homologous to that of EHEC O157:H7), and from bacterial species such as Citrobacter freundii and Hafnia alvei that harbor an eae-like gene (McGraw et al., 1999). Similarly, the stx1 and stx2 gene sequences available from GenBank (Calderwood et al., 1987; Jackson et al., 1987) were used for designing primers and probe sets to amplify and detect 150-bp and 200-bp fragments specific for stx 1 and stx2, respectively. Primers and probes were designed using the Primer Express ${ }^{\circledR}$ software (PE Applied Biosystems, Foster City, CA, USA). The FAM (6-carboxy-fluorescein), VIC (proprietary fluorescent dye developed at PE Applied Biosystems), and TET (6-carboxy-2',4,7,7'-tetrachlorofluorescein) were used as fluorescent 
Table 1

Nucleotide sequence of primers and fluorogenic probes

\begin{tabular}{|c|c|c|c|}
\hline $\begin{array}{l}\text { Primer }^{\mathrm{a}} \text { or } \\
\text { probe }\end{array}$ & Sequence $\left(5^{\prime} \rightarrow 3^{\prime}\right)$ & $\begin{array}{l}\text { Location }^{b} \\
\text { within the } \\
\text { target gene }\end{array}$ & $\begin{array}{l}\text { PCR product } \\
\text { detected (bp) }\end{array}$ \\
\hline stxl-forward & GAC TGC AAA GAC GTA TGT AGA TTC G & $90-114$ & stxl (150) \\
\hline stx1-reverse & ATC TAT CCC TCT GAC ATC AAC TGC & $240-217$ & \\
\hline stxl-probe & TGA ATG TCA TTC GCT CTG CAA TAG GTA CTC & $116-145$ & \\
\hline stx2-forward & ATT AAC CAC ACC CCA CCG & $184-201$ & stx2 (200) \\
\hline stx2-reverse & GTC ATG GAA ACC GTT GTC AC & $392-373$ & \\
\hline stx2-probe & CAG TTA TTT TGC TGT GGA TAT ACG AGG GCT TG & $204-235$ & \\
\hline$e a e$-forward & GTA AGT TAC ACT ATA AAA GCA CCG TCG & $2494-2524$ & $e a e_{\mathrm{O} 157: \mathrm{H} 7}(106)$ \\
\hline eae-reverse & TCT GTG TGG ATG GTA ATA AAT TTT TG & $2599-2574$ & \\
\hline eae-probe & AAA TGG ACA TAG CAT CAG CAT AAT AGG CTT GCT & $2572-2540$ & \\
\hline
\end{tabular}

${ }^{a}$ The nucleotide sequences used in the design of these primers and probes were retrieved from the GenBank using accession numbers M16625 (stx1), X07865 (stx2), and AF081182 (eae $e_{\mathrm{O} 157: \mathrm{H} 7 \text { ). }}$ ).

${ }^{\mathrm{b}}$ The positions of the oligonucleotides are listed relative to the initiation codon $(+1$ adenine $)$ of the respective gene.

reporter dyes and conjugated to $5^{\prime}$ ends of probes to detect amplification products specific for $s t x 1$, stx2, and $e a e_{\mathrm{O} 157: \mathrm{H} 7}$, respectively. The quencher dye TAMRA (6-carboxytetramethyl-rhodamine) was attached at the $3^{\prime}$ ends of these probes. Primers and probes were synthesized by Integrated DNA Technologies (Coralville, IA, USA) and PE Applied Biosystems.

\subsection{PCR amplification and quantitation of stx1, stx2, and eae $0157: H 7$}

PCR was performed in a total volume of $50 \mu \mathrm{l}$ containing $2.5 \mu \mathrm{l}$ of extracted DNA, $10 \mathrm{mM}$ Tris- $\mathrm{HCl}(\mathrm{pH} 8.3), 50 \mathrm{mM} \mathrm{KCl}, 3.5 \mathrm{mM} \mathrm{MgCl}_{2}, 0.2 \mathrm{mM}$ deoxynucleoside triphosphates, $0.3 \mu \mathrm{M}$ of $s t x l$ and $e a e_{\mathrm{O} 157: \mathrm{H} 7}$ primers, $1.5 \mu \mathrm{M}$ of $s t x 2$ primers, $0.1 \mu \mathrm{M}$ of each fluorogenic probe, $60 \mathrm{nM}$ of reference dye ROX (carboxy-X-rhodamine), and $2.5 \mathrm{U}$ of AmpliTaq Gold DNA polymerase (PE Applied Biosystems). Amplification and detection were carried out in optical-grade 96-well plates in an ABI Prism 7700 sequence detection system (PE Applied Biosystems) with an initial cycle of $95{ }^{\circ} \mathrm{C}$ for $10 \mathrm{~min}$ followed by 40 cycles of $94{ }^{\circ} \mathrm{C}$ for $20 \mathrm{~s}, 55^{\circ} \mathrm{C}$ for $30 \mathrm{~s}$, and $72{ }^{\circ} \mathrm{C}$ for $45 \mathrm{~s}$. The final extension was carried out at $72{ }^{\circ} \mathrm{C}$ for 5 min followed by cooling of samples to $25^{\circ} \mathrm{C}$. Reaction conditions for amplification and parameters for fluorescence data collection were programmed into a Power Macintosh 4400/20 (Apple Computer, Santa Clara, CA, USA) linked directly to the ABI Prism 7700 sequence detection system using the SDS 1.6 application software as per manufacturer's instructions. After real-time data acquisition, the cycle threshold $\left(C_{\mathrm{T}}\right)$ value was calculated by determining the point at which fluorescence exceeds an arbitrary threshold signal (10-fold higher than the base line). The threshold signal was manually set so that it intersected the amplification curves in the linear region of semilog plot. The $C_{T}$ value is predictive of the quantity of target gene copies in the PCR sample (Heid et al., 1996). 


\subsection{Preparation of feces and tissues for PCR}

Feces and tissues used in this study were obtained from weaned calves and neonatal cesarean section-derived, colostrums-deprived (CDCD) pigs, respectively, that were the subjects of an ongoing study investigating the mechanisms of colonization of EHEC O157:H7 in cattle (Dean-Nystrom et al., 1997; Dean-Nystrom et al., 1999). These animals were inoculated via a stomach tube with $10^{10} \mathrm{CFU}$ of a streptomycin-resistant EHEC O157:H7 strain 86-24 (stx2 $2^{+}$and $e a e^{+}$; Griffin et al., 1988; McKee et al., 1995). Bovine feces were collected 2 and 3 days post-inoculation, and porcine intestinal tissues (cecum and ileum) were taken at necropsy at 2 days after inoculation. Feces and tissues (1-4 g) were homogenized in peptone broth (30 ml final volume) at 30,000 rpm for $1 \mathrm{~min}$ using a microprocessor-controlled homogenizer (VIRTIS, Gardiener, NY, USA). Ten-fold dilutions of homogenates were plated on SMAC agar containing streptomycin to enumerate the inoculated strain. For DNA preparation, feces and tissue homogenates were centrifuged $(2 \mathrm{~min}$ at $1000 \times g)$ to remove large fecal particles and tissue debris, respectively. Supernatants $(1 \mathrm{ml})$ were centrifuged $(12,000 \times g)$, bacterial pellets suspended in $0.2 \mathrm{ml}$ of a lysis solution (10 mM Tris- $\mathrm{HCl}, 1 \mathrm{mM} \mathrm{Na} \mathrm{A}_{2}$-EDTA $(\mathrm{pH} 8.0)$ and $0.05 \%$ Triton $\mathrm{X}-100)$, heated $\left(100{ }^{\circ} \mathrm{C}\right.$ for $\left.10 \mathrm{~min}\right)$ and then centrifuged $(12,000 \times g$ for $5 \mathrm{~min})$. DNA was recovered from supernatants $(0.1 \mathrm{ml})$ using a kit designed for the purification of PCR products as per manufacturer's directions (Qiagen, Valencia, CA, USA). DNA was used immediately in PCR assay or stored at $-70{ }^{\circ} \mathrm{C}$ for later use. DNA was also prepared from 10-fold serial dilutions of an overnight culture of EHEC O157:H7 $\left(\right.$ st $x 1^{+}$, st $x 2^{+}$, and $\left.e a e^{+}\right)$ strain 2409 (Sharma et al., 1999). Bacterial cells were collected from serial dilutions by centrifugation and processed for DNA isolation as described previously except that the supernatants recovered after $100{ }^{\circ} \mathrm{C}$ heat treatment were not column purified before use in the PCR assay.

\subsection{Preparation of fecal enrichments}

Feces used for determining the effect of enrichment on detection sensitivity of the R-PCR assay were collected from healthy cattle housed at the Animal Nutrition Study Farm, Iowa State University, Ames, IA, USA. These feces were tested for the presence of endogenous EHEC O157:H7 and STEC. For this, $1 \mathrm{~g}$ of feces were mixed with $9 \mathrm{ml}$ of GNTSB, incubated for $16 \mathrm{~h}$ at $37^{\circ} \mathrm{C}$, and centrifuged $(2 \mathrm{~min}$ at $1000 \times \mathrm{g})$ to remove large particles. Culture supernatant $(1 \mathrm{ml})$ was centrifuged $(12,000 \times g$ for $3 \mathrm{~min})$ and the cell pellet was processed to isolate DNA (as described above). This DNA was used in PCR assays with primers listed in Table 1 to amplify and detect fragments specific for $s t x 1$, st $x 2$, and $e a e_{\mathrm{O} 157: \mathrm{H} 7}$. The amplification products were analyzed by electrophoresis through a $4 \%$ agarose gel (FMC BioProducts, Rockland, ME, USA) followed by ethidium bromide staining. The molecular size of bands was estimated from a 50-bp DNA ladder (Roche Diagnostic Laboratories, Indianapolis, IN, USA). Feces that produced no detectable stx- and $e a e_{\mathrm{O} 157: \mathrm{H} 7}$-specific fragments on preliminary screening were used for preparing enrichment cultures. Enrichment cultures were prepared by seeding $1 \mathrm{~g}$ portions of feces with 10-fold serial dilutions of an overnight culture of EHEC O157 strain 2409. Inoculated feces were mixed with $9 \mathrm{ml}$ of GNTSB and incubated at $37{ }^{\circ} \mathrm{C}$ with shaking. After 4 and 
$16 \mathrm{~h}$ incubations, 1-ml samples were removed and processed for isolation of genomic DNA by the procedure described previously.

\section{Results}

\subsection{Specificity of real-time PCR assay}

Genomic DNAs from an E. coli O26 $\left(e a e^{+}\right), \mathrm{O} 111\left(\right.$ st $x 1^{+}$and $\left.e a e^{+}\right), \mathrm{O} 45\left(\right.$ st $x 2^{+}$and $\left.e a e^{+}\right), 0157: \mathrm{NM}\left(e a e^{+}\right)$, and $\mathrm{O} 157: \mathrm{H} 7\left(\right.$ st $x 1^{+}$, st $x 2^{+}$, and $\left.e a e^{+}\right)$were tested initially to establish that primers and probes used in the PCR assay resulted in amplification and detection of amplicons specific to stx1, stx2, and $e a e_{\mathrm{O} 157: \mathrm{H} 7}$ genes. Fig. 1 shows a correlation between a fluorescence signal and cycle numbers for each of the three probes. Fluorescent signal 10-fold higher than the standard deviation of the mean baseline emission was indicative of a positive detection. As shown in Fig. 1, stx1-, stx2-, and $e a e_{\mathrm{O} 157: \mathrm{H} 7}$-specific probes produced exponential increase in fluorescence only when DNA from strains containing these genes was used as a template in the PCR assay. The amplified products generated in samples shown in Fig. 1 were also analyzed on a $4 \%$ agarose gel by standard horizontal gel electrophoresis. Samples resulting in an exponential increase in fluorescence with a particular probe also contained an amplicon of predicted size corresponding to the gene detected by the probe (data not shown). On additional testing of several other strains in the R-PCR assay, a positive amplification profile was produced only for those strains that harbored genes encoding for Shiga toxins and EHEC O157:H7specific intimin (Table 2). Since EPEC O55:H7 harbors an eae homologue of eae $e_{\mathrm{O} 157: \mathrm{H} 7}$, members of this serotype also produced a positive amplification signal with $e a e_{\mathrm{O} 157: \mathrm{H} 7}$ primers and probe set.

\subsection{Detection sensitivity of real-time PCR in pure cultures}

Genomic DNAs prepared from 10-fold serial dilutions of an overnight culture of EHEC O157:H7 strain 2409 were used as templates to determine detection sensitivity of R-PCR and to construct standard curves by plotting colony-forming units (CFUs) versus threshold cycle $\left(C_{T}\right)$ produced for each of the three target genes. The results are shown in Fig. 2. Standard curves showed a linear relationship between the $\log _{10}$ input CFUs and the $C_{T}$ (PCR cycle at which the fluorescent intensity raises above the threshold). The slopes of the curves for stx 1 , stx 2 , and $e a e_{\mathrm{O} 157: \mathrm{H} 7}$ were $-1.41,-1.48$, and -1.50 and the squared regression coefficients after the linear regression for these genes ranged from 0.96 to 0.98 . The three primers and probe sets produced similar amplification yields and fluorogenic detection of target genes. The lowest detection limits of the PCR assay for $e a e_{\mathrm{O} 157: \mathrm{H} 7}$ and stx genes were approximately $20 \mathrm{CFU} / \mathrm{PCR}$ reaction (equivalent to $10^{3} \mathrm{CFUs} / \mathrm{ml}$ ).

\subsection{Detection of EHEC O157:H7 in feces and tissues}

Feces and intestinal tissues from animals infected with EHEC O157:H7 (st $x 2^{+}$and $e a e^{+}$) strain $86-24$ were tested to evaluate the utility of the R-PCR assay for detecting 

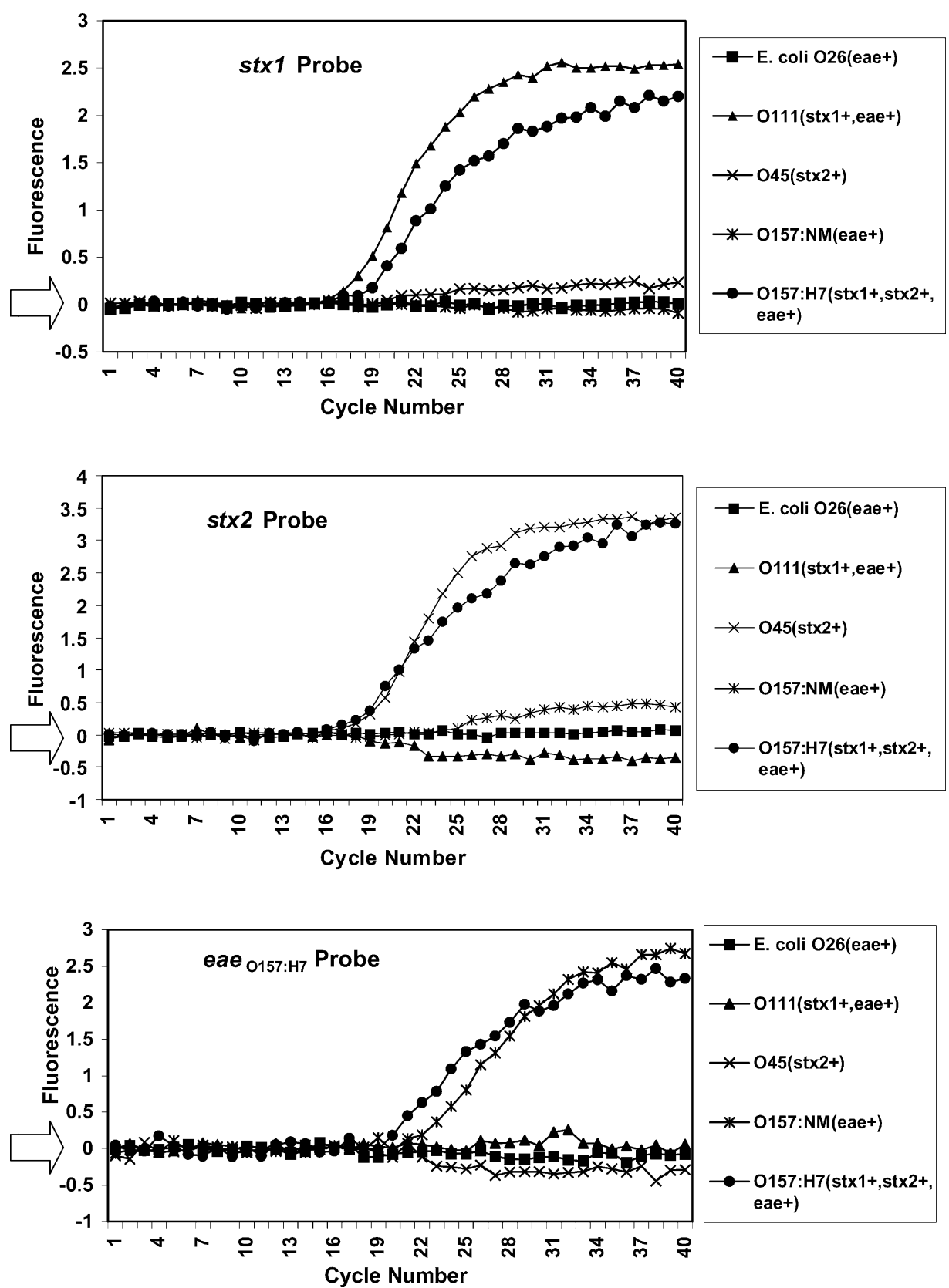

Fig. 1. Real-time PCR profiles for stx1, stx2, and eae $e_{\mathrm{O} 157: \mathrm{H} 7}$ amplification. DNA extracted from five E. coli strains belonging to serotype O26, O111, O45, and O157 were tested in R-PCR using primer and probe sets designed to amplify and detect sequences specific to stx 1, stx2, and eae ${ }_{\mathrm{O} 157: \mathrm{H} 7}$. The relative fluorescence of each sample was plotted against PCR cycle number. The threshold fluorescence or the level at which the threshold cycle was determined is indicated by an arrow on the left. 
Table 2

Specificity of real-time PCR for stx1, stx2, and $e a e_{\mathrm{O} 157: \mathrm{H} 7}$ amplification

\begin{tabular}{|c|c|c|c|c|c|}
\hline \multirow[t]{2}{*}{ Bacterial strains } & \multirow[t]{2}{*}{ Genotype $^{\mathrm{a}}$} & \multirow{2}{*}{$\begin{array}{l}\text { No. strains } \\
\text { tested }\end{array}$} & \multicolumn{3}{|c|}{ No. strains detected with probes specific for } \\
\hline & & & stxl & stx 2 & $e a e_{\mathrm{O} 157: \mathrm{H} 7}$ \\
\hline \multirow[t]{3}{*}{ STEC } & $\operatorname{stx} 1^{+}$ & 37 & 37 & 0 & 0 \\
\hline & stx $2^{+}$ & 40 & 0 & 40 & 0 \\
\hline & stx $1^{+}$, stx $2^{+}$ & 14 & 14 & 14 & 0 \\
\hline \multirow[t]{3}{*}{ EHEC O157:H7 } & stx $1^{+}, e a e^{+}$ & 1 & 1 & 0 & 1 \\
\hline & $s t x 2^{+}, e a e^{+}$ & 3 & 0 & 3 & 3 \\
\hline & $s t x 1^{+}, s t x 2^{+}, e a e^{+}$ & 7 & 7 & 7 & 7 \\
\hline \multirow[t]{2}{*}{ EHEC O26 } & $s t x 1^{+}, e a e^{+}$ & 2 & 2 & 0 & 0 \\
\hline & $s t x 1^{+}, s t x 2^{+}, e a e^{+}$ & 1 & 1 & 1 & 0 \\
\hline \multirow[t]{2}{*}{ EHEC O111 } & $s t x 1^{+}, e a e^{+}$ & 3 & 3 & 0 & 0 \\
\hline & $\operatorname{stx} 1^{+}$, stx $2^{+}, e a e^{+}$ & 2 & 2 & 2 & 0 \\
\hline EPEC O55 & $\operatorname{stx} 1^{-}$, stx $2^{-}, e a e^{+}$ & 3 & 0 & 0 & 3 \\
\hline Other $E$. coli strains ${ }^{\mathrm{b}}$ & $\operatorname{stx} 1^{-}$, stx $2^{-}, e a e^{+}$ & 16 & 0 & 0 & 0 \\
\hline Hafnia alvei & $\operatorname{stx} 1^{-}$, stx $2^{-}, e a e^{+}$ & 1 & 0 & 0 & 0 \\
\hline Other bacterial species ${ }^{\mathrm{c}}$ & $s t x 1^{-}$, st $x 2^{-}, e a e^{-}$ & 8 & 0 & 0 & 0 \\
\hline
\end{tabular}

\footnotetext{
${ }^{\text {a }}$ The virulence factor presence (+) or absence (-) previously established by a PCR assay (Sharma et al., 1999).

${ }^{\mathrm{b}}$ Other E. coli tested were members of the enterotoxigenic E. coli (ETEC), enterpathogenic E. coli (EPEC), attaching and effacing $E$. coli (AEEC).

${ }^{\mathrm{c}}$ Other bacterial species tested were Enterobacter cloacae, Citrobacter freundii, Proteus vulgaris, Klebsiella pneumoniae, Yersinia enterocolitica, Salmonella enterica serovar Typhimurium, Pseudomonas aeruginosa, and Staphylococcus aureus.
}

EHEC O157:H7 in cattle and swine. The DNA isolated from 10-fold serial dilutions of an overnight GNTSB culture of EHEC O157:H7 strain 2409 was used in this assay to construct standard curves for genes stx 2 and $e a e_{\mathrm{O} 157: \mathrm{H} 7}$. The CFUs of EHEC O157:H7 present per gram of tissues or feces were interpolated from these standard curves and compared to bacterial counts determined by plating the same fecal and tissue samples on SMAC-streptomycin agar plates (Table 3). The CFUs per gram of feces or tissues estimated by the R-PCR assay using stx2 and $e a e_{\mathrm{O} 157: \mathrm{H} 7}$ probes were similar to those determined by plating the same samples on SMAC.

\subsection{Detection of EHEC O157:H7 in feces following enrichment}

Enrichment of feces, artificially contaminated with EHEC O157:H7 strain 86-24 and enriched for 4 or $16 \mathrm{~h}$, allowed detection of as few as $25 \mathrm{CFUs} / \mathrm{g}$ of feces with the $e a e_{\mathrm{O} 157: \mathrm{H} 7}$ probe. The detection range was linear over DNA concentrations corresponding to an initial inoculum of $10^{0}$ to $10^{5} \mathrm{CFU}$ of EHEC O157:H7/g of feces (Fig. 3). The detection ranges for stx 1 and stx 2 were very similar to that of the eae gene except that the detection sensitivity was $1 \log$ higher $(2.5 \mathrm{CFU} / \mathrm{g}$ of feces) for st $x$ genes (data not shown). 


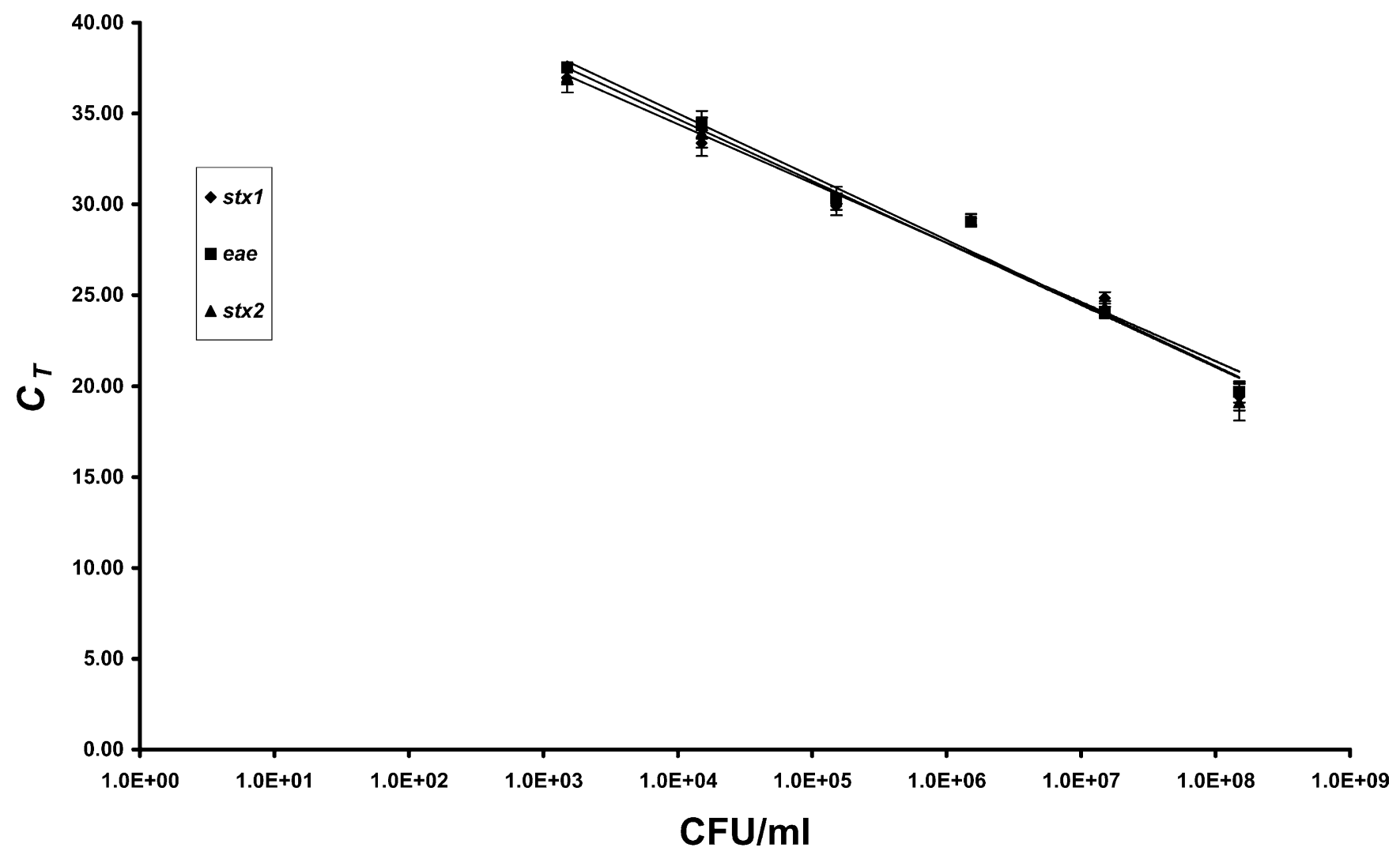

Fig. 2. Sensitivity of R-PCR. DNA extracted from 10-fold serial dilutions of an overnight culture of EHEC O157:H7 strain $2409\left(s t x 1^{+}\right.$, stx2 $2^{+}$, and $\left.e a e^{+}\right)$was tested with $s t x 1-$, stx2-, and $e a e_{\mathrm{O} 157: \mathrm{H} 7}$-specific primer and probe sets. The cycle threshold $\left(C_{\mathrm{T}}\right)$ values are plotted against bacterial growth $(\mathrm{CFU} / \mathrm{ml})$ of each dilution as determined by plating on SMAC-streptomycin agar. The straight lines calculated by linear regression yielded regression coefficients $\left(R^{2}\right)$ of $0.966,0.982,0.971$ for stxl, stx2, and $e a e_{\mathrm{O} 157: \mathrm{H} 7}$, respectively. Error bars indicate the standard deviations based on three PCR reactions. 


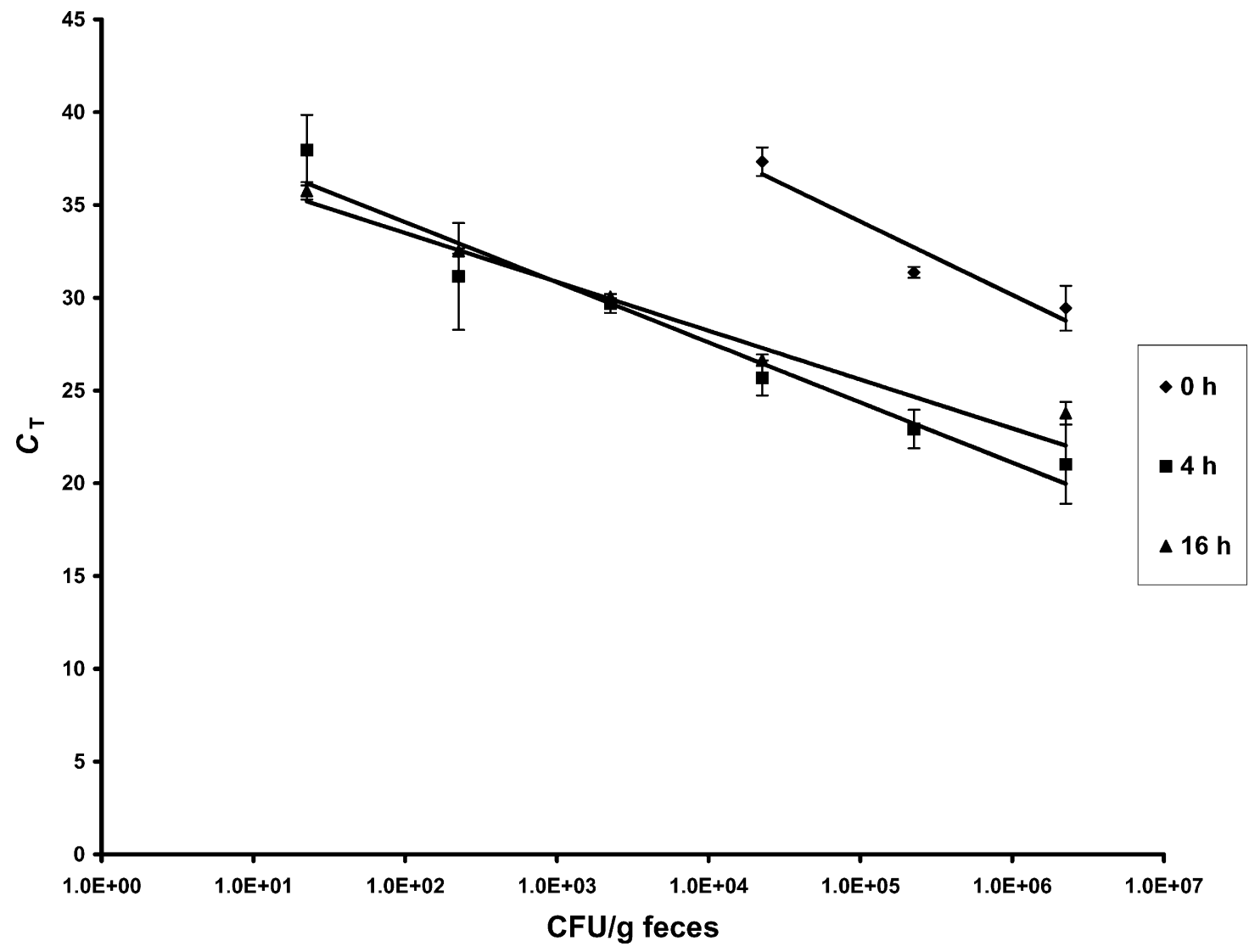

Fig. 3. Effect of enrichment on detection sensitivity of R-PCR. To detect very low levels of EHEC O157:H7, DNA prepared from fecal enrichments was tested in the RPCR assay as described in Section 2. The cycle threshold $\left(C_{\mathrm{T}}\right)$ values were plotted against CFUs present in each serial dilution that was added to a fecal sample before enrichment (determined by plating on SMAC-streptomycin agar). The straight lines calculated by linear regression yielded regression coefficients $\left(R^{2}\right)$ of $0.92,0.96,0.95$ for 0,4 , and $16 \mathrm{~h}$ enrichments, respectively. Error bars indicate the standard deviations based on three PCR reactions. 
Table 3

Detection of EHEC O157:H7 in feces and tissues

\begin{tabular}{|c|c|c|c|c|}
\hline \multirow[t]{2}{*}{ Animal number } & \multirow[t]{2}{*}{ Sample type ${ }^{a}$} & \multicolumn{2}{|c|}{ Real-time $\mathrm{PCR}^{\mathrm{b}}$} & \multirow[t]{2}{*}{ Plate counts ${ }^{\mathrm{c}}$} \\
\hline & & eae probe & stx 2 probe & \\
\hline \multicolumn{5}{|l|}{ Calves } \\
\hline 325 & Pre-feces & ND & ND & $\mathrm{ND}^{\mathrm{d}}$ \\
\hline 325 & 2-Day feces & 6.6 & 7.1 & 6.5 \\
\hline 325 & 3-Day feces & 6.3 & 6.7 & 7.4 \\
\hline 356 & Pre-feces & ND & ND & ND \\
\hline 356 & 2-Day feces & 5.4 & 6.2 & 5.3 \\
\hline 356 & 3-Day feces & 3 & 3.5 & 4.2 \\
\hline \multicolumn{5}{|l|}{ Pigs } \\
\hline 306 & Cecum & 8.1 & 8.2 & 7 \\
\hline 306 & Ileum & 7.9 & 7.6 & 8 \\
\hline 308 & Cecum & 9.1 & 9.1 & 8.6 \\
\hline 308 & Ileum & 6.3 & 6.1 & 7.8 \\
\hline 314 & Cecum & 7.2 & 7.5 & 7.9 \\
\hline 314 & Ileum & 7.3 & 7.3 & 7 \\
\hline 324 & Cecum & 9 & 9.3 & 9.2 \\
\hline 324 & Ileum & 7.7 & 7.9 & 7.9 \\
\hline
\end{tabular}

${ }^{a}$ Pre-feces were collected from weaned calves before inoculation with $10^{10} \mathrm{CFU}$ of EHEC O157:H7 strain

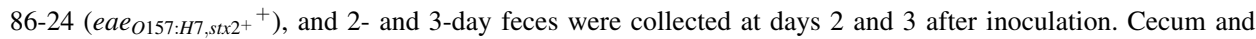
ileum tissues were collected from neonatal CDCD pigs 2-days after inoculation.

${ }^{\mathrm{b}} \mathrm{Log}_{10} \mathrm{CFUs} / \mathrm{g}$ estimates were based on average of three PCR reactions.

${ }^{\mathrm{c}} \log _{10} \mathrm{CFUs} / \mathrm{g}$ sample estimated.

${ }^{\mathrm{d}}$ ND: Not detected. (Detection limits of real-time PCR and plating of samples on SMAC agar were $\geq 10^{3} \mathrm{CFU} / \mathrm{g}$ ).

\section{Discussion}

Real-time PCR (R-PCR) assays that have recently been developed for the identification of EHEC O157:H7 are based on the detection of genes encoding Shiga toxins (Belanger et al., 2002; McKillip and Drake, 2000) or intimin (Oberst et al., 1998) or O antigen (Fortin et al., 2001). These assays, therefore, do not facilitate simultaneous detection of multiple virulence markers associated with EHEC O157:H7. The aim of this study was to develop a multiplex R-PCR assay for rapid and semi-automated detection and quantification of EHEC O157:H7 over a wider detection range by using three sets of primers and fluorogenic probes enabling amplification and immediate detection of gene stx 1 , stx 2 , and $e a e_{\mathrm{O} 157: \mathrm{H} 7}$ in a single test tube. Testing DNA from several STEC serotypes and other E. coli strains and bacterial species verified the specific detection of these genes. The specificity of this PCR assay for detecting these genes was comparable to that reported for other R-PCR assays (Ibekwe et al., 2002; Oberst et al., 1998). Of the bacterial strains tested, only EHEC

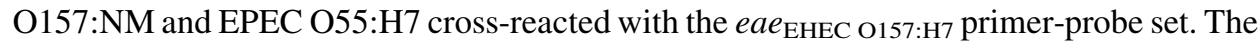
reasons and significance of this cross-reactivity have been discussed in several previous 
publications (Bilge et al., 1996; Feng et al., 1996; Gannon et al., 1997b; Louie et al., 1994; Whittam et al., 1993).

The detection range of the R-PCR assay for $s t x$ and $e a e_{\mathrm{O} 157: \mathrm{H} 7}$ was linear when DNAs prepared from samples containing from $10^{3}$ to $10^{8} \mathrm{CFUs} / \mathrm{ml}$ of EHEC 0157:H7 were used in this assay. This detection range is comparable to R-PCR assays that targeted stx (Belanger et al., 2002; McKillip and Drake, 2000) or eae (Oberst et al., 1998) or $r f b E$ for detecting EHEC O157:H7 (Fortin et al., 2001). Overall, the detection range of R-PCR was three-four orders of magnitude higher than that of an end-point PCR (detection range from approximately $10^{3}$ to $10^{4} \mathrm{CFUs} / \mathrm{ml}$ (Sharma et al., 1999). All three primer and probe sets performed optimally in R-PCR as evidenced by the generation of almost identical slopes and squared regression coefficients.

The optimized R-PCR was evaluated for detecting three virulence markers in feces and tissues recovered from cattle and pigs inoculated with EHEC O157:H7. By using a simple and rapid bacterial DNA isolation procedure, we were able to detect as low as $10^{4}$ CFUs of EHEC O157:H7/g of feces or tissues. The detection range, which was linear between $10^{4}$ and $10^{8} \mathrm{CFUs} / \mathrm{g}$ of feces or tissues, was very similar to that obtained by plating of fecal and tissue samples on a streptomycin-supplemented SMAC plates. However, the routine use of antibiotics in SMAC agar for specific selection and presumptive identification of EHEC O157:H7 in feces, tissues, or foods is precluded because the antibiotic resistance profile of the suspected EHEC O157:H7 isolate would not be known at the time of testing. Therefore, detection sensitivity of SMAC (without an antibiotic) plating will normally be much lower than that of a R-PCR.

By incorporating an enrichment period of 4 and $16 \mathrm{~h}$, the real-time PCR allowed detection of 22 and 2 CFUs/g of feces using eae $e_{\mathrm{O} 157: \mathrm{H} 7}$ and stx probes, respectively. The detection range of $e a e_{\mathrm{O} 157: \mathrm{H} 7}$ and st $x$ genes in enriched samples was linear as long as these samples contained from $10^{0}$ to $10^{5} \mathrm{CFUs} / \mathrm{g}$ of feces at the beginning of enrichment. However, the samples containing $\geq 10^{6}$ CFUs of EHEC O157:H7 before the start of an enrichment period could not be distinguished from each other in their cell counts by the RPCR assay because these samples contained $10^{9} \mathrm{CFUs} / \mathrm{ml}$ post-enrichment (data not shown), and the amount of DNA in these samples was so high that it saturated the amplification process within the first few cycles of PCR.

In summary, the R-PCR assay described in this study is sensitive and accurate method for specific detection and profiling of virulence markers of EHEC 0157:H7 in complex samples such as feces and tissues. In addition, the real-time PCR format enables construction of standard curves that can be used for estimating concentration of EHEC O157:H7 or other STEC in feces and tissues. However, one potential limitation of this PCR would be the inability to distinguish a non-O157:H7 STEC from an EHEC O157:H7 strain if both were present in the same sample. Nonetheless, the capability for simultaneous detection of stxl, stx2, and eae $e_{\mathrm{O} 157: \mathrm{H} 7}$ genes is important for rapid screening of feces and tissues to presumptively identify highly virulent EHEC 0157:H7 from other less virulent serotypes, which are frequently isolated from asymptomatic carrier animals and healthy humans (Karmali, 1989). Moreover, this PCR assay represents an improvement over other real-time PCR assays that have either been developed for detecting only the Shiga toxinencoding genes (Belanger et al., 2002; McKillip and Drake, 2000) or a single gene specific to EHEC O157:H7 (Fortin et al., 2001; Oberst et al., 1998). 


\section{Acknowledgements}

The authors would like to thank Robert Morgan and Matt Inbody for expert technical support, and Sandy Johnson for secretarial assistance. We thank Irene Wesley and Richard Zuerner for critical review of this manuscript.

\section{References}

Beebakhee, G., Louie, M., De Azavedo, J., Brunton, J., 1992. Cloning and nucleotide sequence of the eae gene homologue from enterohemorrhagic Escherichia coli serotype O157:H7. FEMS Microbiol. Lett. 70, 63-68.

Belanger, S.D., Boissinot, M., Menard, C., Picard, F.J., Bergeron, M.G., 2002. Rapid detection of Shiga toxinproducing bacteria in feces by multiplex PCR with molecular beacons on the smart cycler. J. Clin. Microbiol. 40, 1436-1440.

Bellin, T., Pulz, M., Matussek, A., Hempen, H.G., Gunzer, F., 2001. Rapid detection of enterohemorrhagic Escherichia coli by real-time PCR with fluorescent hybridization probes. J. Clin. Microbiol. 39, 370-374.

Bilge, S.S., Vary Jr., J.C., Dowell, S.F., Tarr, P.I., 1996. Role of the Escherichia coli O157:H7 O-side chain in adherence and analysis of an $r f b$ locus. Infect. Immun. 64, 4795-4801.

Calderwood, S.B., Auclair, F., Donohue-Rolfe, A., Keusch, G.T., Mekalanos, J.J., 1987. Nucleotide sequence of the Shiga-like toxin genes of Escherichia coli. Proc. Natl. Acad. Sci. U.S.A. 84, 4364-4368.

Dean-Nystrom, E.A., Bosworth, B.T., Cray Jr., W.C., Moon, H.W., 1997. Pathogenicity of Escherichia coli O157:H7 in the intestines of neonatal calves. Infect. Immun. 65, 1842-1848.

Dean-Nystrom, E.A., Bosworth, B.T., Moon, H.W., 1999. Pathogenesis of Escherichia coli O157:H7 in weaned calves. Adv. Exp. Med. Biol. 473, 173-177.

Feng, P., Fields, P.I., Swaminathan, B., Whittam, T.S., 1996. Characterization of non-motile variants of Escherichia coli $\mathrm{O} 157$ and other serotypes by using an anti-flagellin monoclonal antibody. J. Clin. Microbiol. 34, 2856-2859.

Fortin, N.Y., Mulchandani, A., Chen, W., 2001. Use of real-time polymerase chain reaction and molecular beacons for the detection of Escherichia coli O157:H7. Anal. Biochem. 289, 281-288.

Fratamico, P.M., Sackitey, S.K., Wiedmann, M., Deng, M.Y., 1995. Detection of Escherichia coli O157:H7 by multiplex PCR. J. Clin. Microbiol. 33, 2188-2191.

Gannon, V.P., D’Souza, S., Graham, T., King, R.K., 1997a. Specific identification of Escherichia coli O157:H7 using a multiplex PCR assay. Adv. Exp. Med. Biol. 412, 81-82.

Gannon, V.P., D’Souza, S., Graham, T., King, R.K., Rahn, K., Read, S., 1997b. Use of the flagellar H7 gene as a target in multiplex PCR assays and improved specificity in identification of enterohemorrhagic Escherichia coli strains. J. Clin. Microbiol. 35, 656-662.

Griffin, P.M., Ostroff, S.M., Tauxe, R.V., Greene, K.D., Wells, J.G., Lewis, J.H., Blake, P.A., 1988. Illnesses associated with Escherichia coli O157:H7 infections: a broad clinical spectrum. Ann. Int. Med. 109, 705712.

Griffin, P.M., Tauxe, R.V., 1991. The epidemiology of infections caused by Escherichia coli O157:H7, other enterohemorrhagic E. coli, and the associated hemolytic uremic syndrome. Epidemiol. Rev. 13, 60-98.

Hancock, D.D., Besser, T.E., Kinsel, M.L., Tarr, P.I., Rice, D.H., Paros, M.G., 1994. The prevalence of Escherichia coli O157.H7 in dairy and beef cattle in Washington State. Epidemiol. Infect. 113, 199-207.

Heid, C.A., Stevens, J., Livak, K.J., Williams, P.M., 1996. Real-time quantitative PCR. Genome Res. 6, $986-$ 994.

Ibekwe, A.M., Watt, P.M., Grieve, C.M., Sharma, V.K., Lyons, S.R., 2002. Multiplex flourogenic real-time PCR for detection and quantification of Escherichia coli O157:H7 in dairy wastewater wetlands. Appl. Environ. Microbiol. 68, 4853-4862.

Jackson, M.P., Newland, J.W., Holmes, R.K., O’Brien, A.D., 1987. Nucleotide sequence analysis of the structural genes for Shiga-like toxin I encoded by bacteriophage 933J from Escherichia coli. Microb. Pathog. 2, 147-153.

Karmali, M.A., 1989. Infection by verocytotoxin-producing Escherichia coli. Clin. Microbiol. Rev. 2, 15-38. 
Louie, M., de Azavedo, J., Clarke, R., Borczyk, A., Lior, H., Richter, M., Brunton, J., 1994. Sequence heterogeneity of the eae gene and detection of verotoxin-producing Escherichia coli using serotype specific primers. Epidemiol. Infect. 112, 449-461.

Lyons, S.R., Griffen, A.L., Leys, E.J., 2000. Quantitative real-time PCR for Porphyromonas gingivalis and total bacteria. J. Clin. Microbiol. 38, 2362-2365.

McGraw, E.A., Li, J., Selander, R.K., Whittam, T.S., 1999. Molecular evolution and mosaic structure of alpha, beta, and gamma intimins of pathogenic Escherichia coli. Mol. Biol. Evol. 16, 12-22.

McKee, M.L., Melton-Celsa, A.R., Moxley, R.A., Francis, D.H., O’Brien, A.D., 1995. Enterohemorrhagic Escherichia coli $\mathrm{O} 157: \mathrm{H} 7$ requires intimin to colonize the gnotobiotic pig intestine and to adhere to HEp-2 cells. Infect. Immun. 63, 3739-3744.

McKillip, J.L., Drake, M., 2000. Molecular beacon polymerase chain reaction detection of Escherichia coli O157:H7 in milk. J. Food Prot. 63, 855-859.

Nogva, H.K., Rudi, K., Naterstad, K., Holck, A., Lillehaug, D., 2000. Application of 5'-nuclease PCR for quantitative detection of Listeria monocytogenes in pure cultures, water, skim milk, and unpasteurized whole milk. Appl. Environ. Microbiol. 66, 4266-4271.

Oberst, R.D., Hays, M.P., Bohra, L.K., Phebus, R.K., Yamashiro, C.T., Paszko-Kolva, C., Flood, S.J., Sargeant, J.M., Gillespie, J.R., 1998. PCR-based DNA amplification and presumptive detection of Escherichia coli O157:H7 with an internal fluorogenic probe and the $5^{\prime}$ nuclease (TaqMan) assay. Appl. Environ. Microbiol. 64, 3389-3396.

Paton, A.W., Paton, J.C., 1998. Detection and characterization of Shiga toxigenic Escherichia coli by using multiplex PCR assays for stx1, stx2, eaeA, enterohemorrhagic E. coli hlyA, rfbO111, and rfbO157. J. Clin. Microbiol. 36, 598-602.

Ramotar, K., Waldhart, B., Church, D., Szumski, R., Louie, T.J., 1995. Direct detection of verotoxin-producing Escherichia coli in stool samples by PCR. J. Clin. Microbiol. 33, 519-524.

Sharma, V.K., Dean-Nystrom, E.A., Casey, T.A., 1999. Semi-automated fluorogenic PCR assays (TaqMan) for rapid detection of Escherichia coli $\mathrm{O} 157: \mathrm{H} 7$ and other shiga toxigenic E. coli. Mol. Cell. Probes. 13, 291-302.

Wells, J.G., Davis, B.R., Wachsmuth, I.K., Riley, L.W., Remis, R.S., Sokolow, R., Morris, G.K., 1983. Laboratory investigation of hemorrhagic colitis outbreaks associated with a rare Escherichia coli serotype. J. Clin. Microbiol. 18, 512-520.

Whittam, T.S., Wolfe, M.L., Wachsmuth, I.K., Orskov, F., Orskov, I., Wilson, R.A., 1993. Clonal relationships among Escherichia coli strains that cause hemorrhagic colitis and infantile diarrhea. Infect. Immun. 61, 1619-1629.

Witham, P.K., Yamashiro, C.T., Livak, K.J., Batt, C.A., 1996. A PCR-based assay for the detection of Escherichia coli Shiga-like toxin genes in ground beef. Appl. Environ. Microbiol. 62, 1347-1353. 